UDC: 39:572.1/.4:004

DOI: https://doi.org/10.32689/2617-

2224-2019-18-3-87-99

\title{
Bobrovskyi Oleksii Illich,
}

Assistant of Applied Mathematics and Information Technologies Department of State Higher Educational Institution, 'Pridneprovsk State Academy of Civil Engineering and Architecture', 49000, Dinipro, Tytova str., 2, tel.: +38 (097) 57874 75, e-mail: bobelur@meta.ua

ORCID: 0000-0001-7395-7477

\section{Бобровський Олексій Ілліч,} асистент кафедри прикладної математики та інформащійних технологій, Державний вищий навчальний заклад "Придніпровська державна академія будівництва та архітектури (ПДАБА)”, 49000, Дніпро, вул. Титова, 2, тел.: +38 (097) 5787475, e-mail: bobelur@meta.ua

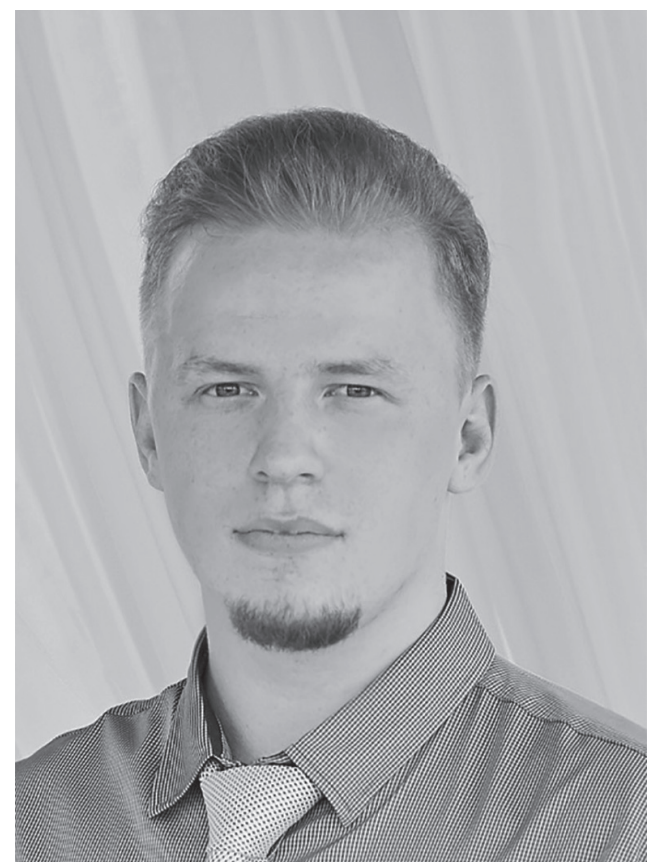

ORCID: 0000-0001-7395-7477

\section{Бобровский Алексей Ильич,}

ассистент кафедры прикладной математики и информационных технологий, Государственное высшее учебное заведение "Приднепровская государственная академия строительства и архитектуры (ПГАСА)”, 49000, Днепр, ул. Титова, 2, тел.: +38 (097) 57874 75, e-mail: bobelur@meta.ua

\section{ARCHETYPES OF UKRAINIAN YOUTH CONSTRUCTION USING THE CONCEPT OF THE 'UNIVERSAL EPOCHAL CYCLE' AND COMPUTER GAMES}

Abstract. The essence of the basic concepts and ways of a new interdisciplinary research area formation and development - social archetypes (the archetypes of the collective unconscious) is shown as the psychological basis of the formation and development of society, its national and cultural identity.

A vision of the archetypal relationship between the consciousness of individuals and the public consciousness as a whole is provided with the impact of the archetypes of the collective unconscious on a person's ability to self-expression, self-affirmation and acquisition of a new democratic worldview, which is significantly influenced by the archetypes of the collective unconscious, which manifest themselves from the childhood. 
The possibilities of the theoretical and methodological design of the 'archetype of Ukrainian youth' are considered, starting with the fundamental principles of its life. The domestic analytical-synthetic model of the 'Universal Epochal Cycle' was taken as the basis for such an implementation. According to this model, the life course of a person is considered by periods, the totality of which, in fact, constitutes a mini-model of the 'human life cycle'. This approach is complemented by the features and the general content of the 'archetypical components' that manifest themselves at each stage of a person's life path.

In the context of the approach, the expediency of creating a cascade process of developing and introducing computer games as an instrument for modeling mental abilities and psychological qualities of an individual at each stage of a person's life path is substantiated. The goal of the games is to choose the development of spirituality, sociality, patriotism and other important social values. It is proposed to construct social processes taking into account the principles of continuity, interconnection, specific living conditions and peculiarities of the stages of human socialization and directing them towards achieving the goals of social development and consistently increasing the complexity of tasks using innovative methods to solve them in the context of the country's sustainable development.

To develop such an 'intelligent algorithm' of innovative technologies for creating the basis for the development of the 'archetype of Ukrainian youth', it is proposed in the article to involve specialists from various fields of knowledge who are most sensitive to understanding the underlying essence (psychosocial or archetypical) of the youth age cohort.

Keywords: the theory of social archetypes, the structure of the elements

of the archetype, the archetype environment, the archetype of the Ukrainian youth, 'The Universal Epochal Cycle', computer games.

\section{КОНСТРУЮВАННЯ АРХЕТИПІВ УКРАЇНСЬКОЇ МОЛОДІ ІЗ ЗАСТОСУВАННЯМ "УНІВЕРСАЛЬНОГО ЕПОХАЛЬНОГО ЦИКЛУ” І КОМП’ЮТЕРНИХ ІГОР}

Анотація. Розглянуто сутність основних понять і шляхів становлення та розвитку нового міждисциплінарного напряму наукових досліджень - соціальної архетипіки (архетипів колективного несвідомого) як психологічного підгрунтя становлення та розвитку суспільства, його національно-культурної ідентичності.

Розроблено візію стосовно архетипного взаємозв'язку між свідомістю окремих особистостей і суспільною свідомістю загалом, впливу архетипів колективного несвідомого на здатність людини до самовираження, самоствердження і набуття нового демократичного світогляду, на який здійснюють свій вплив як генетична спадщина людини, так і архетипи колективного несвідомого, що позначають себе від дитячого віку.

Розглянуто можливості теоретико-методичного конструювання “архетипу української молоді”, починаючи з першооснов ії життя. За основу такої реалізації взято вітчизняну аналітико-синтетичну модель "Універсального 
епохального циклу”. Згідно з цією моделлю життєвий шлях людини розглядається за періодами, сукупність яких, власне, й становить міні-модель “життєвого циклу людини”. Означений підхід доповнюється особливостями та загальним змістом “архетипних складників”, що виявляють себе на кожному етапі життєвого шляху людини.

У контексті підходу обгрунтовано доцільність створення каскадного процесу розробки і запровадження комп’ютерних ігор як інструменту моделювання розумових здібностей і психологічних якостей особистості на кожному етапі життєвого шляху людини. Метою ігор пропонується вибрати розвиток духовності, соціальності, патріотизму та інших важливих суспільних цінностей особистості. Конструювання соціальних процесів пропонується здійснювати із врахуванням принципів спадкоємності, взаємозв'язку, конкретних умов життя і особливостей етапів соціалізації людини та їх спрямування на досягнення цілей розвитку суспільства і послідовного зростання складності завдань з використанням інноваційних методів їх вирішення у контексті сталого розвитку країни.

Для розробки такого “інтелектуального алгоритму” інноваційних технологій створення підгрунтя розвитку “архетипу української молоді” пропонується залучити фахівців різних галузей знань, які найбільш чутливі до розуміння глибинної (психосоціальної або архетипної) сутності молодіжної вікової когорти.

Ключові слова: теорія соціальної архетипіки, структура елементів архетипу, архетипне середовище, архетип молодих українців, “Універсальний епохальний цикл”, комп'ютерні ігри.

\section{КОНСТРУИРОВАНИЕ АРХЕТИПОВ УКРАИНСКОЙ МОЛОДЕЖИ \\ С ИСПОЛЬЗОВАНИЕМ “УНИВЕРСАЛЬНОГО ЭПОХАЛЬНОГО ЦИКЛА” И КОМПЬЮТЕРНЫХ ИГР}

Аннотация. Рассмотрено сущность основных понятий и путей становления и развития нового междисциплинарного направления научных исследований - социальной архетипики (архетипов коллективного бессознательного) как психологической основы становления и развития общества, его национально-культурной идентичности.

Разработано видение относительно архетипной взаимосвязи между сознанием отдельных личностей и общественным сознанием в целом, влияния архетипов коллективного бессознательного на способность человека к самовыражению, самоутверждению и приобретению нового демократического мировоззрения, на которое оказывают существенное влияние как генетическое наследие человека, так и архетипы коллективного бессознательного, проявляющие себя уже с детского возраста.

Рассмотрены возможности теоретико-методического конструирования “архетипа украинской молодежи”, начиная с первооснов ее жизни. В качестве основы такой реализации взята отечественная аналитико-синтетическая модель “Универсального эпохального цикла”. Согласно этой модели, жиз- 
ненный путь человека рассматривается по периодам, совокупность которых, собственно, и составляет мини-модель “жизненного цикла человека”. Указанный подход дополняется особенностями и общим содержанием “архетипических составляющих”, проявляющих себя на каждом этапе жизненного пути человека.

В контексте подхода обоснована целесообразность создания каскадного процесса разработки и внедрения компьютерных игр как инструмента моделирования умственных способностей и психологических качеств личности на каждом этапе жизненного пути человека. Целью игр предлагается выбрать развитие духовности, социальности, патриотизма и других важных общественных ценностей. Конструирование социальных процессов предлагается осуществлять с учетом принципов преемственности, взаимосвязи, конкретных условий жизни и особенностей этапов социализации человека и их направление на достижение целей развития общества и последовательного роста сложности задач с использованием инновационных методов их решения в контексте устойчивого развития страны.

Для разработки такого “интеллектуального алгоритма” инновационных технологий создания основы развития “архетипа украинской молодежи” предлагается привлечь специалистов различных областей знаний, которые наиболее чувствительны к пониманию глубинной (психосоциальной или архетипной) сущности молодежной возрастной когорты.

Ключевые слова: теория социальной архетипики, структура элементов архетипа, архетипная среда, архетип украинской молодежи, “Универсальный эпохальный цикл”, компьютерные игры.

Formulation of the problem. The complicated and contradictory movement of Ukraine towards the European community requires national cohesion, mutual understanding, solidarity, and commitment to concrete actions to preserve and increase the social values and economic well-being. A special role in the country's movement towards the future and its sustainability belongs to the youth, which today is under the influence of many challenges, most of which are concentrated inside the country. They consist of inconsistency of life values, preferences, needs, and the degree of their satisfaction with the criteria of social protection and social development and the conditions for securing economic needs in comparison with developed countries of the world.

As a result, there is a lack of sustainable consolidation among the youth of the country in the event of problems of different nature, loyalty, initiative and voluntary participation in solving existing problems become questionable; decreasing manifestation of pride, patriotism acceptable to Ukrainians. The aforementioned aspects confirm the need to increase attention to the socialization of youth, to give it a proper status in solving public affairs and in government administration. The revival and development of Ukrainian 
youth can contribute to the creation of a kind of "archetypal environment", the gradual and consistent enrichment of its spirituality, the harmonization of youth consciousness with the corresponding archetypes of the collective unconscious, and the world outlook, culture and professionalism - with its participation in solving the problems of the state formation and the degree of intellectual capital growth as psycho-energetic source of personal development.

Analysis of the recent research and publications. The problem of studying the mental abilities of people, peculiar archetypal programs was formulated in the writings of foreign scientists: the German philosopher Immanuel Kant, the Austrian psychiatrist and psychologist Sigmund Freud, the Swiss psychologist and philosopher Carl Gustav Jung and their followers [1-4]. But they considered the development of mental abilities of man at an angle of genetic factors. The scientific generalization, development and methodological approaches to the practical application of the theory of social archetype in Ukrainian society are presented in the writings of E. A. Afonin [5; 6], O. V. Sushiy [9], T. Belska [10; 11], A. Yu. Bolshakova [12], O. A. Donchenko $[13 ; 15]$, O. Yu. Amosov and N. L. Havkalova [16], V. V. Druk [14], V. M. Kozakov [18], and many others [17], that identified the key factors in the formation of a mature archetypal foundation of people as participants in the joint activity and their influence on development processes. These factors are widely used in the scientific research, education and practice systems not only in Ukraine but also abroad. The Ukrainian School of Archetype -
USA - was established and successfully functioning. At the same time, the complexity, novelty and diversity of the questions of the theory of social archetypes create a certain incidence of research that does not cover all the areas of its possible use. The latter concerns the study of the formation of a stable archetype of young Ukrainians, which updates the search for possibilities for its creation.

Purpose of the article: to find out the possibilities of implementing the theory of social archetype in creating conditions for the formation and development of the personality of representatives of the Ukrainian nation. Finding an answer to the question - how to form an archetype of Ukrainian youth in the Ukrainian society that will become an active integrating factor and foundation for the development of the social capital of Ukrainians, who can express their ideology, goals and ensure the dynamic movement of the progressive development of the Ukrainian state.

Presentation of the main material. For Ukraine the $21^{\text {st }}$ century began with the definition of the existing problems of social development, which led to a change in the social behaviour of its population as a result of awareness of changes in the social system, participation in public affairs, the emergence of new dubious opportunities for self-sufficiency and development. This trend has also been observed among young people. However, people's ability to perceive changes in the environment does not come at the same time as the changes come, it takes some time and the creation of the necessary conditions for their revival. As I. Kant argued, "...based on the eternal and immutable 
laws of the mind itself, it is necessary to conduct a study whose object can not be indifferent to human nature" $[1$, p. 11] (translation of the author - O.B.). S. Freud proposed the concept of human psychoanalysis and defined the structure of his psyche, which, in his opinion, consists of the pre-conscious, conscious and unconscious. In the nature of the pre-consciousness is the content of spiritual life that can easily become conscious - emotions, thinking, memory, will. Conscious - this is a personal perception of the outside world, and the unconscious - this is an instinct, and that part of the psyche where the unconscious desires are concentrated, pushed out of the consciousness. In the character of the personality he identified three components: "Ego", "Super-Ego", "Id". "Ego" is formed with the application of the principle of reality, "Super-Ego" is developed on the basis of the principles of awareness of the norms of morality and values that society adheres to, "Id" is formed on the basis of principles of satisfaction and uncontrolled leanings (or impulses). C. Jung, studying the components of the structure of the human psyche, introduced the concept of "archetype", "archetypal structure of the individual", which reflect the ability to a certain type of representation of themselves, the world and accumulated human experience [3]. Emphasizing a large number of archetypes, C. Jung, E. Durkheim, L. Levy-Brühl and others [4] considered them as components of the social evolution - "stimulators" and "de-stimulators" of development and as "regulators" of their tuning. But this did not take into account the importance of the social factors in shaping the behaviour of people (education, environment, level of education, living conditions, professional affiliation, influence on behaviour from the part of society). Therefore, it is difficult to agree with S. Freud's conclusions that the main thing for human development is another person, not the objects that surround her. At the present stage of socio-economic transformations in a society for a person all the factors influencing its psychological state, relations in society, state of health, as well as social, economic, cultural, environmental, political and other factors are important. In various social processes are involved hundreds and thousands of archetypes on various grounds, which under certain conditions can be united, integrated and act on the basis of the collective unconscious.

The current state of the Ukrainian youth can not be considered close to the Ukrainian archetype of a young consciously educated person who has reliable historical roots, developed and established features of the Ukrainian people, the integrity of the social personality to whom hopes can be put into the development of the future Ukrainian state. That is, we can state that a reliable and durable archetype of Ukrainian youth has not yet been created. Thus, young graduated specialists who during the period of studying do not receive proper training in the future field of activity after the defense of a diploma or master's degree work have a negligible opportunity to work for a specialty, do not have a belief in the possibility of their own development in their home country. The awareness of the lack of conditions for self-realization and the realization of the dream, which formed the path during studying, pushes the 
youth to search for their "own happiness" in more developed countries. It takes a lot of time to achieve their ambitious plans. Excessively long-term self-determination and self-assertion leads to a decline in the social capital, discouragement in one's own strengths of both individuals and entire groups, reduces the value orientations of the Ukrainian society. The connection with the destiny of their people, the desire to create decent living conditions in their country, the choice of the role of the creator of their own and the social future - these are the necessary features and characteristics of a person who should be valued by the society and the state, educated, supported and stimulated to preserve the Ukrainian nation.

However, today the state takes care of young people in a certain way. Measures are being taken to support the young family at the birth of a child, in the provision of loans for housing, subsidies for the construction of communal housing, etc., are provided. But, unfortunately, it does not take into account moral values, human intelligence, the desire to increase activity in joint activities, to develop their own qualities necessary to increase the social consciousness that is needed for active Ukrainian, the desire to create conditions for improving life together. Therefore, it is necessary to create a youth stratum of people with an archetypical core that will reflect not only the individual, but also the general nature, the generalized experience of previous generations, encompass the transpersonal universal meaning and act as the ideological basis of people's lives. This archetypal core can be considered as a historical foundation of the mentality of the Ukrai- nian people, its culture, human dignity, respect and harmony of relations, to promote the development of the social community of the people, internal collective behavioural control, reduction and leveling of the undesirable manifestation of the "collective unconscious", increase the social layer of the conscious "Ego" and "Super-Ego". The content of the archetypal core should be based on the best features of the Ukrainian nation and the development of archetypal youth models that are relevant to the modern Ukrainian society. This requires the creation of theoretical and methodological foundations and mechanisms for constructing the archetypes of Ukrainian target orientation, the construction of social technologies for their formation and harmonious development. Mastering the processes of human assimilation of the individual and the collective foundations of the social life and understanding of their own intellectual capabilities in the context of the archetypal concept is a multi-level, end-to-end process. It can be imagined as an unceasing stream of a large number of representations, symbols, situations, knowledge and information in the social space of the human being, inseparable and closely related to each other, the goals of development, which develops the consciousness of man. This influential stream originates from preschool age and encompasses school, educational and professional period, professional life and even retirement period [6, p. 14].

The definition of phased features of the formation of human archetypes and factors influencing the formation of Ukrainian youth is possible through the use of the analytical model of the 
"Universal Epochial Cycle" proposed by the Ukrainian scholars E. Afonin and A. Martynov [6, p. 44-52]. The cycle includes four phases: revolution, involution, co-evolution, and evolution. If we consider the human way of life, then it also consists of separate stages: childhood, adolescence, youth, and the stage of professional and human maturity. And although the stages of the cycle of human existence are different in content and shorter in time, they are filled with profound meaning, are influenced by the historical conditions of existence of the country, contain unlimited changing opportunities of individual and collective processes of formation and consolidation of the archetypes of personality. At each stage of life the conditions of their acquisition and preservation change.

In children's (preschool) age the world perception of the environment is formed on the basis of a sense of love, attention from parents, relatives, educators; contact with fairy tale heroes, their behaviour. At this age there is a rejection of evil, no mercy, injustice, indifference and mistrust. As a child the following traits are brought up: kindness, compassion, desire to come to the help, make a good deed, make friends. As a principle to follow parents and fairy-tale heroes are chosen. Sprouts of dreams about their own volitional characteristics in adult life are born. At the level of the personal unconscious, in the period from 1 to 3 years, the child begins to separate the line of his own "Ego" for the first time.

At junior school age (6-10 years) the influence of fairy tales gradually decreases and pupils' dreams are almost unrelated to fabulous heroes. It forms their own understanding of the future, it creates an idea about the development of the necessary knowledge and qualities for the imaginary profession. During this period "Ego" and "SuperEgo" are becoming actively formed, understanding their influence on the achievement of their own identity with the environment.

In the middle age (10-15 years) the formation of spiritual traits of the character and morality dominates, individualizations and tendencies to selfimmolation, aspiration for independent decision-making, freedom of expression and personal freedom, certain rules of behaviour are formed, the choice of future professional activity is determined more precisely.

The worldview is intensively formed at the senior school age (15-17 years), the understanding of the natural and fundamental laws of reality is deepened, new knowledge is acquired in the world of future professions in conditions of their manifestation and existing possibilities of their mastering. There is an understanding of the limits, constraints and possibilities of own development. The directions of spiritual development are diversified, the purposeful volitional willingness to act in the chosen direction is formed, the social modeling of the future life status is strengthened, and the "Super-Ego" is actively formed.

In the student age (17-22 years) begins to actively develop and further influence the life (22-29 years) the collective unconscious. Getting acquainted with the senior students' youth, communicating with classmates, forming social groups by interests, adjusting to mastering the chosen profession creates an understanding of the competitive ad- 
vantages and features of leadership, the desire to compete for a certain place and self-affirmation in the student's society appears. At this stage there are abilities and aspirations for the role of the leader or role of the subordinate or the role of the executive. In a new light the historical past is revealed. It becomes clearer about the actual future, the expected and innovative changes in the morality and spirituality of the nation, its continuity, sociality, efficiency, commitment to the protection of dignity, independent, social and economic security, the ability to overcome difficulties and faith in a truly secure future. The ideology of Ukrainian patriotism is being strengthened.

At this stage one can state that the archetype (archetypal mechanisms) of a young, professionally educated person was formed, but the structure of its elements, "Ego", "Super-Ego" and the collective unconscious are in a state of further development. Their content may vary and in different ways appear in certain life situations.

Apparently, in the process of professional life the individual unconscious of a person can be substantially changed, and this period needs even more attention. If a young person is left alone with his own problems, he is able to get under the influence of different circumstances of life and substantially change his individual "Ego" and the individual unconscious that will have its consequences.

The above shows that in the process of individual development there is always a place for the construction of archetypes of Ukrainian youth, as should be under the control of society and the state and attract the attention of older generation specialists who are facing the path of youth formation. It is necessary to create a national strategy for the education of a new generation of Ukrainians to continue adopting and elaborating new reforms in Ukraine. Its key task should be to identify as many types of archetypes of modern youth and create an idea of their structure and conditions for optimal development. Appropriate institutions should also be set up to develop and monitor the implementation of the concept of the revival of Ukrainian youth, which will consist of specialists and have the necessary financial and material support.

Information technology and computer games should become one of the important tools for implementing the process of upbringing and strengthening the archetypes of a young Ukrainian. The use of modern computer information technologies has become one of the most dynamic areas of science and technology development today. Computer technologies are capable of creating broad opportunities for activating and developing intellectual capital of people through the design, construction and implementation of processes of socialization of the individual, including in support of the archetypes of the collective unconscious inherent in the younger generation.

It should be noted that at the present stage the consideration and assessment of the archetypal component of personal development is in some way present: in education and professional activities; in management for determining the psychological compatibility of a person with other people; when forming project teams; in medicine in determining the mental state of a person; in sport with mastering technology of profes- 
sional skill development and in solving other problematic issues.

Today there are a lot of computer games in the country, but the prevailing majority of their subjects are tuned to get acute feelings, to rest, to master new knowledge or practice, and to make money. When investigating the problem of the development of the archetype of young Ukrainians, it is quite appropriate to raise the question of creating a bank of "intellectual games" for each age with clearly defined psychodiagnostic, training and other auxiliary purposes for employing "archetypal grounds" and opportunities for socializing young people. These are the creation of games aimed at the intellectual and social development of youth potential that will stimulate their inner creative activity while at the same time developing and streamlining the computer market of Ukraine, capable of becoming interesting for solving social problems of youth and business development in our country, as well and beyond.

Conclusions and perspectives of further research. The theory of psychosocial analysis and archetype of the collective unconscious contains a great potential for further deep understanding of the essence of man, his culture and social behaviour in the process of formation, development and, in fact, behaviour in various life situations.

The upbringing of socially mature young people capable of comprehending themselves and the world, historical experience and evolution, modernity, as well as awareness of the role and place of the archetypes of the collective unconscious in the modern-postmodern world will allow deepening human understanding, strengthening the tenden- cies for the unification and common activity of people of related nature for their spirituality, culture, social behaviour, interests. After all, the common vision and creation of the future increases the social power and energy of people, their social capital, activates its capabilities to achieve sustainability of the development.

The harmonization of the process of formation, reproduction and development of the psychosocial (archetypal) nature of Ukrainian youth will contribute to a significant reduction of conflict in the social environment, will allow "converting" the archetypal potential of the collective unconscious into the ability and desire of young people to engage in solving social problems at the level of local self-government and society as a whole.

In our opinion, further research and solution of this problem lie in the plane: the study of the structure and content of the components of the archetypes of Ukrainian youth adjacent to the stages of its life; definition of psychosocial types of youth groups and harmoniously acceptable spheres of life, compatibility and direction of their behaviour in the circle "leader - subordinate - executive"; study of common features and professional features of the activities of youth participants in social projects; development of gaming computer technologies for diagnostics and evaluation of the archetypal basis of youth life; study of other related issues of becoming a mature psychosocial type of Ukrainian.

\section{REFERENCES}

1. Kant I. (1994). Sobranie sochineniy [Collected Works]. (Vols. 1-8). Moscow: Choro [in Russian]. 
2. Freud S. (1923). Das Ich und das Es. Retrieved from http://www.psychanalyse.lu/Freud/FreudIchEs.pdf [in German].

3. Jung K. (2009). Soznanie i bessoznatelnoe [Consciousness and unconscious]. Moscow: Akademicheskiy Proekt [in Russian].

4. Jung K. G. (1991). Arkhetip i simvol [The archetype and symbol]. Moscow: Renessans [in Russian].

5. Afonin E. A., Berezhniy Ya. V., Valezskiy O. L., et. al. (2010). Liudska identychnist ta osoblyvosti yii vplyvu na polityku y derzhavne upravlinnia [Human Identity and Peculiarities of its Influence on Politics and Public Administration]. Kontseptualni zasady vzaiemodii polityky i upravlinnia Conceptual Principles of the Interaction of Politics and Management. V. A. Rebkala, et. al. (Eds.). (p. 265289). Kyiv: NADU [in Ukrainian].

6. Afonin E. A., Bandurka A. M., Martynov A. Yu. (2003). Velikaya koevolyutsiya: globalnye problemy sovremennosti: istoriko-sotsialnyy analiz [Great coevolution: global problems of the present: historical and social analysis]. ( $2^{\text {nd }}$ ed., rev.). Kyiv: Parlamentskoe izd-vo [in Russian].

7. Blagodeteleva-VovkS.(2011). Kachestvennye i kolichestvennye metody vyyavleniya arkhetipov [Qualitative and quantitative methods for identifying archetypes]. Publichne upravlinnya: teoriya ta praktika - Public Administration: Theory and Practice, Special Issue, 6-11 [in Russian].

8. Novachenko T. V. (2013). Arkhetypova paradyhma avtorytetu kerivnyka $\mathrm{V}$ derzhavnomu upravlinni [Archetype paradigm of the authority of the head of the state administration]. E. A. Afonina (Eds.). Nizhyn-Kyiv: Vydavets Lysenko M. M. [in Ukrainian].

9. Sushyi O. V. (2012). Psykho-sotsialna kultura derzhavnoho upravlin- nia [Psychosocial Culture of Public Administration]. Kyiv: Svitohliad [in Ukrainian].

10. Bielska T. V. (2015). Vlada i suspilstvo: arkhetypnyi pidkhid [Power and Society: An Archetypal Approach]. Problemy mizhnarodnykh vidnosyn Problems of International Relations, 10-11, 200-213 [in Ukrainian].

11. Bielska T. V. (2014). Arkhetypni kontseptualni zasady stanovlennia i rozvytku hlobalnoho hromadianskoho suspilstva [Archetypical conceptual principles of formation and development of global civil society]. Publichne upravlinnia: teoriia ta praktyka Public administration: theory and practice, 2(18), 14-22 [in Ukrainian].

12. Bolshakova A. Yu. (2010). Arkhetip kontsept - kultura [Archetype - concept - culture]. Voprosi filosofii Questions of philosophy, 7, 47-57 [in Russian].

13. Donchenko O. A. (2012). Arkhetypovyi menedzhment [Archetype management]. Kirovohrad: Imeks-LTD [in Ukrainian].

14. Druk V. (2015). Arkhetypy komunikatyvnoi diialnosti yak osnova stalykh vidnosyn derzhavy i suspilstva [Archetypes of communicative activity as the basis of the lasting relations between the state and society]. Publichne upravlinnia: teoriia ta praktyka - Public Administration: Theory and Practice, 1, 24-27 [in Ukrainian].

15. Donchenko O., Romanenko Yu. (2001). Arkhetypy sotsialnoho zhyttia i polityka (Hlybynni rehuliatyvy psykholohichnoho povsiakdennia) [Archetypes of social life and politics (Deep regulating the psychological everyday life)]. Kyiv: Lybid [in Ukrainian].

16. Amosov O. Yu., Havkalova N. L. (2016). Symbioz instytutsiinykh zasad ta arkhetypiky publichnoho upravlinnia [Symbiosis of institutional foundations and archetype of public admi- 
nistration]. Publichne uriaduvannia Public administration, 2(3), 15-22 [in Ukrainian].

17. Sushyi O. V. (2016). Teoretychni zasady sotsialnoi arkhetypyky [Theoretical Foundations of Social Archetype]. Publichne uriaduvannia - Public administration, 3(4), 168-180 [in Ukrainian].

18. Kozakov V. M. (2017). Ukrainska mentalnist yak arkhetypnyi faktor harmonizatsii suspilno-vladnykh vidnosyn [Ukrainian mentality as an archetypal factor of the harmonization of socialauthority relations]. Publichne uriaduvannia - Public administration, 3(8), 127-135 [in Ukrainian].

\section{СПИСОК ВИКОРИСТАНИХ ДЖЕРЕЛ}

1. Кант И. Собрание сочинений: в 8 т. (комплект). - М. : Чоро, 1994. $4592 \mathrm{c}$.

2. Sigmund Freud. Das Ich und das Es (1923) [Електронний ресурс]. Режим доступу: http://www. psychanalyse.lu/Freud/FreudIchEs. pdf

3. Юнг К. Сознание и бессознательное. - М. : Академ. проект, 2009. 188 с. - (Психологические технологии).

4. Юнг К. Г. Архетип и символ. - М.: Ренессанс, 1991. - 343 с. - (Страницы мировой философии).

5. Афонін E. А. Людська ідентичність та особливості її впливу на політику й державне управління / Е. А. Афонін // Концептуальні засади взаємодії політики і управління : навч. посіб. / авт. кол. Е. А. Афонін, Я. В. Бережний, О. Л. Валевський [та ін.]; за заг. ред. В. А. Ребкала [та ін.]. - К. : НАДУ, 2010. - С. 265289.

6. Афонин Э. А. Великая коэволюция: глобальные проблемы современ- ности: историко-социальный анализ: монография / Э. А. Афонин, А. М. Бандурка, А. Ю. Мартынов. 2-е изд., перераб. и доп. - К. : Парламентское изд-во, 2003. - 384 с.

7. Благодетелева-Вовк C. Качественные и количественные методы выявления архетипов / С. Благодетелева-Вовк // Публічне управління: теорія та практика: зб. наук. пр. Асоціації д-рів наук з держ. управління. - Спец. вип. - 2011. - С. 611.

8. Новаченко T. В. Архетипова парадигма авторитету керівника в державному управлінні : монографія / Т. В. Новаченко ; за наук. ред. Е. А. Афоніна. - Ніжин-Київ : Вид. Лисенко М. М., 2013. - 320 с.

9. Суший О. В. Психосоціальна культура державного управління: монографія / О. В. Суший. - К. : Світогляд, 2012. - $344 \mathrm{c}$.

10. Бєльська Т. В. Влада і суспільство: архетипний підхід / Т. В. Бєльська // Проблеми міжнародних відносин : зб. наук. пр., 2015. - Вип. 1011. - C. 200-213.

11. Бєльська T. В. Архетипні концептуальні засади становлення і розвитку глобального громадянського суспільства / Т. В. Бєльська // Публічне управління : теорія та практика : зб. наук. пр. Асоціації д-рів наук з держ. управління. - 2014. № 2 (18) (спец. вип.). - С. 14-22.

12. Большакова А. Ю. Архетип - концепт - культура / А. Ю. Большакова / Вопросы философии. - 2010. № 7. - C. 47-57.

13. Донченко О. А. Архетиповий менеджмент : монографія / О. А. Донченко. - Кіровоград : Імекс-ЛТД, 2012. - $264 \mathrm{c}$.

14. Друк B. Архетипи комунікативної діяльності як основа сталих відносин держави і суспільства / В. Друк // Публічне управління : те- 
орія та практика: зб. наук. пр. Асоціації д-рів наук з держ. управління. 2015. - № 1 (спец. вип.). - С. 24-27.

15. Донченко О. Архетипи соціального життя і політика (Глибинні регулятиви психологічного повсякдення) : монографія / О. Донченко, Ю. Романенко. - К. : Либідь, 2001. - 334 с.

16. Амосов О. Ю. Симбіоз інституційних засад та архетипіки публічного управління / О. Ю. Амосов, Н. Л. Гавкалова // Публічне уря- дування : зб. - 2016. - № 2 (3). C. $15-22$.

17. Суший О. В. Теоретичні засади соціальної архетипики / О. В. Суший // Публічне урядування. - 2016. № 3 (4). - C. 168-180.

18. Козаков В. М. Українська ментальність як архетипний фактор гармонізації суспільно-владних відносин / В. М. Козаков // Публічне урядування : збірник. - 2017. - № 3 (8) (спец. вип.). - С. 127-135. 